\title{
ResearchArticle
}

\section{Effect of different additives for the production of lignocellulolytic enzymes (liquid medium) in Volvariella volvacea}

\author{
A. Sudha and M. Rajesh
}

\section{SUMMARY}

Among the additives liquid culture amended with calcium carbonate was found to be superior for the production of exo $\beta$-1,4 glucanase $(17.51 \mu \mathrm{mol}$ of glucose $/ \mathrm{ml})$, endo $\beta$-1,4 glucanase $(18.39 \mu \mathrm{mol}$ of glucose $/ \mathrm{ml}), \beta$-glucosidase $(23.21 \mu \mathrm{mol}$ of p-nitrophenol $/ \mathrm{ml})$, xylanase $(0.26 \mu \mathrm{mol}$ of xylose $/ \mathrm{ml})$, laccase $(0.17 \mathrm{OD}$ change $/ \mathrm{min} / \mathrm{ml})$ and polyphenol oxidase $(0.24$ OD change $/ \mathrm{min} / \mathrm{ml})$. This was followed by horse gram powder $(16.83 ; 17.54 ; 20.95 ; 0.21 ; 0.14$ and 0.21$)$, calcium carbonate $+\operatorname{gypsum}(16.28 ; 17.07 ; 20.66 ; 0.20 ; 0.13$ and 0.20$)$ as against $13.33 ; 15.48 ; 19.05 ; 0.17 ; 0.10$ and 0.17 in non-amended medium (control).

Key Words : Volvariella volvacea, Organic, Inorganic additives, Enzyme production, Liquid medium

How to cite this article : Sudha, A. and Rajesh, M. (2019). Effect of different additives for the production of lignocellulolytic enzymes (liquid medium) in Volvariella volvacea. Internat. J. Plant Sci., 14 (2): 69-73, DOI: 10.15740/HAS/IJPS/14.2/69-73, Copyright@ 2019: Hind Agri-Horticultural Society.

Article chronicle : Received : 20.02.2019; Revised : 05.06.2019; Accepted : 15.06.2019

\section{MEMBERS OF THE RESEARCH FORUM}

Author to be contacted :

A. Sudha, Department of Plant Pathology, Tamil Nadu Agricultural

University, Coimbatore (T.N.) India

Email : sudhaa1981@gmail.com

Address of the Co-authors:

M. Rajesh, Centre of Excellence for Millets, Athiyandal (T.N.) India 